Joanna Wygnańska

Instytut Socjologii

Uniwersytet Łódzki

\title{
Tożsamość zorientowana na heterogeniczność. Dyskurs postjugosłowiańskiej serbskiej tożsamości narodo- wej a idea członkowstwa Republiki Serbii w Unii Europejskiej
}

Naród serbski jest najstarszy na świecie, z niego powstały wszystkie inne narody, a od języka serbskiego pochodzq wszystkie inne języki. Ale jest on jednocześnie narodem najmłodszym i najświeższym, on niesie światu zaczątek ogólnoludzkiego lub przynajmniej ogólnoeuropejskiego odrodzenia. Jest to możliwe, jako że naród ów istnieje na uboczu czasu historycznego, bezpowrotnego trwonienia historii. Żyje w czasie wiecznej teraźniejszości, stary i młody zarazem, $w$ wiecznie trwajacym zgromadzeniu martwych, żyjących i tych, którzy się dopiero narodzą.

(Čolović 2001: 18-19; Mit o serbskim narodzie)

\section{Wstęp}

Dyskursywne konstruowanie tożsamości narodowej przypisuje słowu moc działania. „Poprzez dyskurs aktorzy społeczni konstytuują wiedzę, sytuację, społeczne role jak i również identyfikacje i interpersonalne relacje pomiędzy poszczególnymi grupami społecznymi pozostającymi w interakcji. Co za tym idzie, akty społeczne są społecznie konstytuowane na kilka sposobów. Po pierwsze odgrywają decydującą rolę w genezie, produkcji i konstrukcji poszczególnych warunków społecznych. Dlatego też dyskursy mogą służyć do konstruowania narodowej tożsamości. Po drugie, mogą uwiecznić, reprodukować lub uprawomocnić pewne status quo (i narodowych tożsamości z nim powiązanych). Po trzecie, są instrumentalnie wykorzystywane przy próbach zmian status quo (i narodowych tożsamości z nim powiązanych). Po czwarte, praktyki dyskursywne mogą przynieść efekt w postaci rozbicia, a nawet zniszczenia status quo (i narodowych tożsamości z nim powiązanych)" (Cillia, Reisigl, Wodak 1999: 57). Badacze tego podejścia odwołują się pojęciowo do koncepcji upatrujących naród w kategoriach wspólnoty wyobrażonej (przede wszystkim do tez Benedicta Andersona). Procesualny, zmienny charakter tożsamości skłonił badaczy do przyjęcia interpretacji tożsamości jako narracji. „Po pierwsze, narody są tu rozumiane jako mentalne konstrukty, jako polityczne wspólnoty wyobrażone [...] po drugie zakładamy, że 
narodowe tożsamości - postrzegane są jako szczególna postać tożsamości zbiorowych - są dyskursywnie produkowane, reprodukowane, transformowane i niszczone przez język i inne systemy semiotyczne" (tamże 1999: 153). Konstruowanie tożsamości narodowej odbywa się poprzez dyskurs, który obejmuje w szczególności wypowiedzi ustne i pisemne skupiające się wokół pojęcia „naród” i wyrażone figurą retoryczną „My”. Wytyczone w ten sposób granice w postrzeganiu pojęć „My” i „Oni” oraz to jak nas owi „Oni” widzą, obejmują listę elementów składających się na: „rozmaite dyskursy tożsamości narodowej konstytuowane przez intelektualistów oraz przez kulturę symboliczną" (Bokszański 2001: 92).

W przypadku postjugosłowiańskiej serbskiej tożsamości narodowej bardzo wyraźny jest proces dyskursywnego jej konstruowania. Na dyskurs ten składają się kwestie: rozumienia narodu, świadomości narodowej i tożsamości, konstruowania przeszłości, teraźniejszości i przyszłości politycznej oraz strategie konstruowania i rekonstruowania tożsamości narodowej. Dyskurs ten należy omawiać w odniesieniu do optyki temporalnej: przeszłości i teraźniejszości samowiedzy serbskiej tożsamości narodowej oraz wskazując obszary dyferencjacji dające się wyodrębnić w tym dyskursie. Chodzi tutaj o te elementy dyskursu, które wyraźnie odróżniają serbską tożsamość narodową od innych postbałkańskich tożsamości. Należą do nich: język, religia i etnomit polityczny. Konsekwencją tych różnic są antagonizmy: serbsko-chorwacki i serbskoalbański, silnie wpływające na wymiar konstruowania serbskiej przeszłości, teraźniejszości i przyszłości politycznej.

Dla znajdującej się w fazie transformacji serbskiej tożsamości narodowej kolejnym dyskursywnym konstruktem jest także tożsamość europejska będąca efektem realizacji idei integracji europejskiej. Republika Serbii złożyła oficjalny wniosek o członkowstwo w Unii Europejskiej 16 grudnia 2009 roku. Złożenie tego wniosku jest kolejnym krokiem prozachodniego rządu koalicyjnego w Belgradzie na drodze do unijnego członkowstwa. Wcześniej, w kwietniu 2008 roku, Serbia podpisała umowę o stowarzyszeniu i współpracy z UE. Idea członkostwa byłej republiki jugosłowiańskiej w strukturach Unii Europejskiej jest wyzwaniem ekonomicznym, politycznym, kulturowym, ale także tożsamościowym. Wiąże się z przepracowaniem historycznej pamięci i redefinicją narracji serbskiej tożsamości narodowej. 
Głównym tematem niniejszego tekstu jest założenie o znaczącym wpływie okcydentalnej perspektywy europejskiej na serbski nacjonalizm. Z perspektywy bałkańskiej jest on naturalną formą akcentowania swojej „heterogeniczności”, „odmienności”. Europejskie, okcydentalne spojrzenie traktować go może jednak jako niezdrową i niebezpieczną „religię” polityczną, która zamiast pielęgnować narodowe świętości, wykorzystuje ich symbolikę do tworzenia przekazów charakterystycznych dla języka wrogości. W ten sposób z perspektywy europejskiej postrzegane jest m. in. nieprzychylne stanowisko Republiki Serbii wobec ogłoszenia niepodległości Kosowa. Dla Serbii prowincja Kosowo jest od wieków kluczowym historycznym i symbolicznym elementem jej pamięci zbiorowej. Dodatkowo, Serbia nigdy nie żywiła sympatii wobec jakichkolwiek działań świata zachodniego ingerujących w jej stosunki z innymi republikami byłej Jugosławii. Dlatego też proeuropejskie dążenia rządu koalicyjnego w Belgradzie postawiły przed Republiką długoterminowe zadanie przeformułowania konstruktów zakorzenionych w politycznej i społecznej serbskiej mentalności. Należą do nich opozycje pojęć: „dobra Serbia” versus „zła Europa” oraz „gorsza Serbia” versus „lepsza Europa”. Przy czym ten drugi dipol nawiązuje bezpośrednio do sytuacji podkreślania przez zachodnie (europejskie) media - barbarzyńskiego i nieeuropejskiego charakteru zachowań Serbii w czasie ostatniej wojny bałkańskiej. Dość systematycznie zaznaczały one również przynależność Chorwacji do kultury i świata europejskiego, wyrażały głęboki żal wobec Bośni i Hercegowiny oraz krytykowały agresywny, niecywilizowany styl polityki serbskiej (Čolović 2001: 54).

Serbia jest krajem, dla którego tożsamość europejska nie jest warunkiem wstępnym dla budowania idei integracji europejskiej. Proponowana więc przez dyskurs elit politycznych i naukowych perspektywa top down nie funkcjonuje w przypadku tego kraju. Tożsamość europejska będzie tu raczej efektem zrealizowania polityki akcesyjnej. Warunkiem koniecznym jest natomiast dostosowanie się do politycznych i ekonomicznych wymogów stawianych przez Unię Europejską.

Jugo-serbia. podwaliny serbskiego nacjonalizmu

Bałkany można nazwać przestrzenią „dryfującej” tożsamości. To na tym obszarze w ciągu dziejów: „(...) członkowie tego samego plemienia, ludu czy narodu (...) bywali obywatelami królestw nie tylko różnych, ale i śmiertelnie sobie wrogich. Chwalili Boga w cerkwi, kościele, meczecie, 
w słowiańskim obrządku głagolickim, prawosławnym, greckim, unickim, rzymskim, luterańskim; szukali Go w tajemniczych obrzędach Bogumiłów i w mistyce hesychastów. Walczyli przeciw sobie w armiach wszystkich potęg, dla których Bałkan był bramą na Wschód lub Zachód, którym porty Adriatyku, Morza Czarnego i Śródziemnego miały otworzyć drogę do kolejnych podbojów" (Dąbrowska-Partyka, 1995: 39). Zmitologizowana przestrzeń projektów ideologicznych jednego państwa południowych Słowian była fundamentem wspólnoty narodowej. Jej granice projektowali dziewiętnastowieczni głosiciele idei jugoslawizmu. Projekty te różniły się między sobą w zależności od tego, który z ośrodków kulturowych pełnił rolę dominującą: Zagrzeb (ośrodek chorwacki) czy Belgrad (ośrodek serbski). Problemem dla stworzenia syntetycznej kultury stały się jednak cywilizacyjno-historyczne różnice przejawiające się $\mathrm{w}$ treściach tradycji kulturowych, zawierających zalążki odrębnych kultur narodowych Serbii i Chorwacji. W wyniku zarysowywania się owych różnic przez cały XIX wiek toczyła się rywalizacja dwóch centrów integracyjnych: zagrzebskiego i belgradzkiego. Rozpoczęła się - jak sugeruje Joanna Rapacka: „walka o dusze ludzkie, a jej przedmiotem byli przede wszystkim ci, których samoidentyfikacja narodowościowa z powodów historycznych była chwiejna, bądź wręcz nie istniała" (Rapacka 2002: 447). Doprowadziła ona do porażki idei narodu iliryjskiego czy jugosłowiańskiego oraz serbskich i chorwackich ideologii ekskluzywnych, dążących do poszerzenia własnych przestrzeni kulturowych. Jak stwierdza historyk Marek Waldenberg: ,jeszcze w przeddzień wybuchu wojny bałkańskiej (1912-1913), panowało przekonanie, że Chorwaci i Serbowie stanowią jeden naród. (...) Z czasem dyferencjacja stawała się coraz większa, poczucie tożsamości narodowej coraz powszechniejsze i głębiej zakorzenione" (Waldenberg 2003: 54).

W lipcu 1917 roku na wyspie Korfu doszło do pertraktacji między władzą serbską a Komitetem Londyńskim skupiającym polityków austro-węgierskich, opowiadających się po stronie jugosłowiańskiej opcji połączenia wszystkich południowych Słowian w niezależnym królestwie pod serbską egidą (rządami dynastii Karadziordziewiczów). Dwa miesiące wcześniej w austriackiej Radzie Państwa został utworzony Klub Jugosłowiański popierający połączenie wszystkich zamieszkujących ziemie monarchii Słoweńców, Chorwatów i Serbów w jedno państwo pod dynastią Habsburgów (Waldenberg, 2003: 55). Rok później zostało proklamowane w Belgradzie (1 grudnia 1918 r.) utworzenie Królestwa Serbów, 
Chorwatów i Słoweńców. W styczniu 1929 roku, dekretem królewskim nazwa państwa została przemianowana na Królestwo Jugosławii. Jugoslawizm stał się ideologią Karadjordjeviciowskiego reżimu, która znajdowała zwolenników głównie wśród Serbów ze względu na zakorzenioną $\mathrm{w}$ tradycji serbskiej ideę złączenia narodu $\mathrm{z}$ państwem jako podstawowego kryterium identyfikacji narodowej. Naród jugosłowiański był postrzegany jako poszerzony naród serbski (Rapacka 2002: 441). Do głosu dochodziły coraz częściej przejawy niezadowolenia Chorwatów i Słoweńców, wynikające z centralistycznej władzy partii serbskich.

W tym samym roku w Chorwacji została powołana do życia nielegalna skrajnie nacjonalistyczna organizacja Ustaša, której celem było prowadzenie działań rewolucyjnych na rzecz odłączenia Chorwacji od Królestwa Jugosławii. W 1939 roku doszło do porozumienia między rządem a chorwackimi politykami, którego skutkiem, stało się utworzenie autonomicznej Banowiny Chorwackiej, obejmującej ziemie etnograficznie i historycznie chorwackie (Waldenberg 2003: 61). W niespełna dwa lata później Królestwo Jugosławii rozpadło się z powodu najazdu niemieckich sił zbrojnych. Co ciekawe, jak pisze Waldenberg, hitlerowcy dążyli jedynie do walki z Serbami, podkreślając, że naród niemiecki nie ma żadnego powodu by walczyć przeciw Chorwatom i Słoweńcom.

Jugoslawizm dziewiętnastowieczny był jedną z postaci środkowoeuropejskiego słowianofilstwa oraz posiadał emancypacyjno-wolnościowy charakter. Dopiero w XX wieku, za sprawą przesunięcia się jego ośrodka na wschód, zamienił się $\mathrm{w}$ „autorytarną bałkańską ideologię narodowopaństwową, odbieraną przez inne narody jako forma nacisku" (Rapacka 2002: 451) Powstała po drugiej wojnie światowej Socjalistyczna Federacyjna Republika Jugosławii składała się z sześciu republik: Serbii, Chorwacji, Bośni i Hercegowiny, Czarnogóry, Słowenii i Macedonii oraz dwóch okręgów autonomicznych Wojwodiny i Kosowa w ramach Serbii.

Odbudowę Jugosławii traktowano jako coś naturalnego, nie widząc innej alternatywy. Bardzo szybko jednak dała się we znaki sprzeczność między zasadami nowego lepszego zjednoczenia a komunistycznym systemem społeczno-politycznym. W efekcie tego konfliktu nową ideologią stał się zreformowany jugoslawizm. Jego wymowa polegała na poszanowaniu odrębności kultur narodowych, ale stanowiła również zaporę przeciw zrywom nacjonalistycznym. „Ta sofistyczna konstrukcja, charakterystyczna dla komunistycznych ideologów, zmuszała do 
nieustannego lawirowania między Scyllą unitaryzmu a Charybdą nacjonalizmu, każdorazowo wyznaczoną przez ideologów" (tamże 2002: 452). Ceną za uznanie praw narodowych w Jugosławii, było potępienie narodowych ideologii, pociągające za sobą usuwanie z pamięci zbiorowej narodów dużych połaci przestrzeni historycznych. W przypadku Chorwacji jedyną zaakceptowaną sferą pamięci zbiorowej stała się tradycja iliryzmu do 1848 roku. Pierwiastki serbskiej myśli historycznej w większości zostały potępione, jako składniki wielkoserbskiej ideologii, a także jako elementy międzywojennego jugoslawizmu unitarnego. Znacznie zmarginalizowano prawosławie i dążono do ograniczenia cyrylicy. Nawet jeśli założymy, że Jugosławia nie była „sztucznym państwem", była na pewno społeczną konstrukcją, zakładającą wykreowanie wspólnej przestrzeni społecznej. Z punktu widzenia socjologicznego była więc przestrzenią społecznego konstruowania rzeczywistości w wieloetnicznej wspólnocie.

Zła pamięć powoływała jednak do życia mit rodzimej rdzennej kultury, który niósł za sobą procesy dezintegracji i wrogości wewnątrz zatomizowanej społeczności. „W dualistycznie podzielonym świecie poszukiwanie tożsamości niebezpiecznie łatwo przybierało obraz terroru stereotypów. Im bardziej nieprzyjazne, odmienne i nieprzeniknione były twarze Obcych, tym bardziej umacniała się Nasza wartościowa odmienność. Jak perpetuum mobile działał mechanizm „tożsamości negatywnej", ożywiając kolejne obszary złej pamięci" (Dąbrowska-Partyka 1995: 41). W powstałym $\mathrm{w}$ ten sposób świecie autostereotypów, zbiorową wyobraźnię zdominowały ludowa i romantyczna legenda. To one uformowały kształt historycznej pamięci, czyniąc z niej solidną podstawę zbiorowej autoidentyfikacji. Powstałe na Bałkanach nacjonalistyczne ideologie i koncepcje słowiańskiego federalizmu opierały się więc na rozpamiętywaniu tego: „co Nam uczyniono, a nie tego, do czego sami byliśmy zdolni” (tamże 1995: 41).

Kilkudziesięcioletnia próba homogenizacji nastawionych jednak na heterogeniczność tożsamości narodowych nie powiodła się. Dyskurs serbskiej tożsamości narodowej na początku lat 90-tych był pochodną nacjonalistycznej polityki Slobodana Miloševicia zainicjowanej w 1989 roku, bazującej na politycznych etnomitach i resentymentach. Jugosłowiański pisarz Mirek Kovač w wywiadzie udzielonym w 1991 roku mówił: „Dziś Serbia, jeśli idzie o demokrację, jest najbardziej zacofanym krajem w Europie. Siłą napędową obecnej serbskiej polityki jest nacjona- 
lizm. Jeżeli człowiek krytykuje dzisiejszą serbską władzę od razu otrzymuje etykietę serbofoba lub zdrajcy" (Łatuszyński 1997: 103).

Postjugosłowiańska Serbia.

Nacjonalizm radykalny i nacjonalizm umiarkowany

Między narodem a baśniq̨ istnieje szczególny zwiq̨zek.

(Jean-Francis Lyotard)

Zdaniem serbskiego intelektualisty Ivana Čolovicia - dyskurs o polityce i narodzie Serbii - sprowadza się do baśni. Korelaty tej baśni stanowią wszelkie tematy narodowe, takie jak serbski naród, serbskie państwo, serbska ziemia. Baśń jest narracją, a dla przedstawienia ważnych tematów narodowych właśnie po narracyjne metody powinno się sięgać. „Można to wyjaśnić wyższością baśni nad innymi rodzajami mowy polityki w czasach, kiedy pojawia się potrzeba jak najszybszego zrekonstruowania na nowych podstawach i umocnienia wizerunku narodu jako wspólnoty wyobrażonej oraz władzy nad symbolami mocy politycznej, osłabionymi po rozpadzie reżimu komunistycznego, po rozpadzie państwa" (Čolović 2001: 15). Baśń staje się idealnym przekaźnikiem tradycji narodowych ze względu na reguły jej fabulacji. Umożliwia sensowną ciągłość często niespójnych bądź sprzecznych historycznych wydarzeń. Taka „narracyjna temporalność” pozwala na bezpośredni związek teraźniejszości z przeszłością. Jak podkreśla Čolović istnieje tu tak zwane praesens historicus, które stwarza wrażenie, że minione już wydarzenia rozgrywają się obecnie, jesteśmy ich naocznymi świadkami. Ponadto mamy do czynienia z użyciem "tradycyjnego czasu epickiego - na przykład perfectum", który sprawia, że opowiadanie o wydarzeniach współczesnych nie odbywa się w oderwaniu od przeszłości (tamże 2001: 15). Ich poprawna interpretacja i zrozumienie możliwe staje się w oparciu o mity istniejące w zbiorowej pamięci narodu. W dyskursie opowieści narracyjnej nie pojawia się problem wiarygodności mówiącego i jego wypowiedzi. Z założenia narrator jest tu wszechwiedzący. Zastosowanie tego założenia do baśni o narodzie i polityce pozwala na kreowanie niepodważalnej wizji prawdy w oparciu o autorytet narratora.

Dyskurs o polityce i narodzie serbskim to baśń, której ciąg mniej lub bardziej powiązanych fabuł, stanowi wzorzec poprawnego zbiorowego myślenia i postępowania. Fabuły te w języku politycznym można nazwać politycznymi fabułami mitycznymi lub po prostu mitami. Ściślej mówiąc, są to „serbskie mity etnonacjonalistyczne”. 
W postjugosłowiańskiej Serbii dominują ponadto baśnie populistyczne. Można je odnaleźć, „w języku, jakim mówi się w polityce, w mediach kontrolowanych przez reżim, oraz w bliższej reżimowi literaturze i publicystyce naukowej" (Čolović 2007: 51). W popularnych baśniach o władzy, podmiotem snującym narrację jest naród. W baśniach populistycznych, naród staje się zbiorowym bohaterem narracji. Najważniejszym aspektem jest podział ról. Baśń populistyczna mówi o zasługach dobrego bohatera, jakim jest naród, ale także o zdrajcach i wrogach, którzy spełniają zadanie bohaterów negatywnych. Przykładem takiego podziału są dwa wystąpienia. Pierwsze z nich wygłosił - po zakończeniu wojny w Kosowie - Milošević, przypisując Narodowi Serbskiemu rolę bohatera. Drugie zaś, to wystąpienie Slobodana Tomovicia, ministra energetyki, który o wrogach Narodu wypowiada się następująco: „Zły los wydał na nas wyrok i oto stale wystawieni jesteśmy na ataki zdobywców. I zawsze znajdzie się jakiś przechrzta, który swoją wiarę odda za okruchy z pańskiego stołu. Paktowi NATO w momencie historycznej niepewności także pomogli nato-janczarzy. W dawnych czasach serbskie dzieci zabierano za granicę, aby tam uczyły się nienawiści do ojczyzny, a dziś nasi janczarzy wyjeżdżają $\mathrm{w}$ świat po pieniądze i za pieniądze uczą się tam, jak zdradzać swój kraj i naród" (dziennik Politika, 08. 07. 2007). Zdrajcy Narodu są winni z natury rzeczy i dlatego potępia się ich często za to, co dopiero zrobią, a nie za dokonane już działania.

Baśń populistyczna posiada jeszcze jedną ważną cechę, a mianowicie zdejmuje historyczną, polityczną i moralną odpowiedzialność za wodzów. Istnieją także takie wersje omawianej baśni, w których mówi się przede wszystkim o wadach Narodu Serbskiego po to, aby zapowiedzieć wielkie zmiany, swoiste odrodzenie się tego bohatera, które ma nadejść w niedalekiej przyszłości. Motyw cierpienia traci tutaj eschatologiczny wymiar, nie wieńczy go wstąpienie do królestwa niebieskiego, a raczej wpisuje się on w fabułę epopei traktującej o długiej bitwie prowadzącej do osiągnięcia wspólnego królestwa na tym świecie. Duchowe zjednoczenie Narodu Serbskiego nie jest celem lecz środkiem politycznego i terytorialnego zjednoczenia.

Na specyfikę dyskursu serbskiej tożsamości narodowej w latach 1992-2005 składały się teksty o charakterze nacjonalizmu radykalnego produkowane i reprodukowane w formie baśni oraz mitów etnonacjonalistycznych. Nacjonalizm radykalny można tu inaczej rozumieć jako nacjonalizm o wizerunku etnicznie „ekskluzywnym”. Zdaniem J.G. Kellesa 
nacjonalizm etnicznie „ekskluzywny” (exclusive), to inaczej nacjonalizm wschodni. Nacjonalizm etnicznie „inkluzywny” (inclusive) jest nacjonalizmem zachodnim. „Oznacza to, że w sytuacji przewagi tego drugiego obywatele zamieszkujący dane terytorium są akceptowani jako członkowie narodu i mogą tworzyć <<państwo narodowe>>, natomiast w warunkach supremacji tego pierwszego prawo to otrzymują tylko ci, którzy dysponują prawidłową wiarygodnością etniczną" (Konarski 2006: 21).

Wojenny i powojenny nacjonalizm serbski został bezpośrednio zainicjowany przez tekst Kosovo and Unity odczytany przez Slobodana Miloševicia w rocznicę sześćsetlecia bitwy na Kosowym Polu 28 czerwca 1989 roku . Utrzymana w podniosłej retoryce przemowa serbskiego przywódcy przywróciła do dyskursu politycznego mit o Kosowym Polu, a także narzuciła reżim patriotyzmu oparty na opozycji wobec tego, co chorwackie i europejskie (Daković 2004: 203).

W micie o serbskiej polityce i serbskim narodzie dawne wątki mitologii etnonacjonalistycznej omawiane są jedynie fragmentarycznie. Čolović podkreśla, że „funkcjonują one jako synekdocha, to znaczy jako pomniejszone wcielenia i szyfry pozwalające włączyć się do specjalnego programu komunikacji (w sensie komputerowym), wkroczyć w mentalny obszar etnonacjonalnej identyfikacji i partycypacji” (Čolović 2001: 20). Jako przykład takiej „synekdochy” Čolović podaje właśnie fragmentaryczne aktualizacje mitu kosowskiego. „Etnonacjonalna identyfikacja” odbywa się za pomocą symboli. Symbolem jest sama nazwa Kosowo ze względu na rozpoznawalność i ważność dla serbskiej etnonacjonalistycznej wspólnoty. Mit kosowski stanowi punkt oparcia dla innych fabuł mitologicznych, przez co orientacja kosowska jest orientacją mityczną.

W maju 1991 roku serbska partia rządząca: „lansuje tezę globalnego zagrożenia, w jakim rzekomo znaleźli się Serbowie nie tylko w Kosowie, w Chorwacji, w Wojwodinie, ale także w samej Serbii, gdyż okrążeni są przez nieprzyjaciół. (...) Rozwijanie bowiem tezy o zagrożeniu jest po prostu aktywizacją ideologii nacjonalistycznej. Jest aktywizacją do użycia siły" (Łatuszyński 1997: 103). Serbska tożsamość kształtowana jest w pierwszych latach po rozpadzie Jugosławii poprzez język propagandy wojennej uwikłany w nadużycia symboli religijnych, animistycznych bądź mitologicznych oraz falsyfikację historycznej przeszłości. Wypowiedzi z pola dyskursu publicznego oscylują między mową nienawiści a „politycznie poprawnym kłamstwem”. Z drugiej strony, w dyskursie 
funkcjonuje także zjawisko „jugonostalgii”, tęsknoty za wspólną jugosłowiańską przestrzenią społeczno-kulturową.

Kolejne lata wplatają w dyskurs serbskiej tożsamości narodowej postjugosłowiańską odmianę niemieckiego nacjonalizmu defensywnego mówiącego o zachowaniu czystości upersonifikowanej tkanki narodowej. W tygodniku „Duga” 10 października 1992 roku ukazał się anonimowy apel skierowany do narodu chorwackiego, głoszący konieczność unikania Serbów. Z przesłania płynęła klarowana wskazówka: „Nie utrzymujcie kontaktów z Serbami i nie przyjaźnijcie się z nimi - w ten sposób zapobiegniecie ich przenikaniu w chorwacką tkankę narodową (Čolović 2001: 45-46). Obawy przed przenikaniem tego, co obce, do naturalnej tkanki macierzystej danej narodowości etnicznej - może wynikać w dużej mierze z samego rozumienia etniczności. Tożsamość etniczna bowiem - także serbska czy chorwacka - bywa wyrażona przez atrybuty niepodlegające kulturowej manipulacji. Symbolami tożsamości etnicznej stają się te cechy, które są postrzegane albo jako wywodzące się z naturalnych czy biologicznych procesów albo najmniej zależne od wolnego wyboru (Bokszański 2008: 68-69). Etniczność, rozumiana jako atrybut naturalny, staje się cennym nośnikiem narodowego „ja”. Jakakolwiek ingerencja w ten ważny obszar wiąże się z jego obumieraniem, a tym samym „zanieczyszczeniem” całej tkanki, co może prowadzić do obumierania całego ciała - symbolicznie i alegorycznie - ciała narodu. Pisał o tym między innymi Aleksander Sołżenicyn, tłumacząc dlaczego w jego mniemaniu - Rosja powinna zgodzić się na niepodległość Czeczenii. Pisarz stwierdził: „Kiedy gangrena przeżarła jedną część ciała, jest oczywiste, że należy ją amputować, aby uratować organizm" (Čolović 2001: 45). W piśmie bośniackich Serbów odnajdujemy tekst, wyrażający strach przed taką amputacją: „Świadomość, że akt podziału serbskich ziem jest prawie nieunikniony i nieuchronny, lękiem i niepewnością napawa serbską substancję narodową ostrą klingą tnie żywą tkankę organizmu serbskiego narodu" (tamże 2001: 46).

W niektórych wersjach serbskiego mitu również Bośnia i Hercegowina stanowią część tkanki narodu serbskiego. W dyskursie o narodzie serbskim pojawiało się także przyrównywanie etnicznej mapy Bośni do skóry lamparta, składającej się z „plam” będących „serbskimi ranami”, doznanymi w toku historii. 
Ostatnią fazą nacjonalizmu radykalnego wpływającego na wymiar zawartości (toposów) serbskiej tożsamości narodowej jest zjawisko „nacjonalistycznego kulturkampfu”. Polega ono na przeniesieniu walki o serbskie terytoria etniczne $\mathrm{z}$ frontu wojny na front kultury. Zgodnie z ideą nowego nurtu: „Pracownicy sprawy narodowej nie kreślą już map przyszłych ziem serbskich, czym z lubością zajmowali się w przededniu i w toku wojen w Chorwacji oraz Bośni i Hercegowinie, za to coraz bardziej koncentrują się na zachowaniu zagrożonej ponoć serbskiej przestrzeni duchowej, czyli narodowej tożsamości. Oparcie znajdują w takim modelu, który traktuje działalność kulturalną, jako jeden z elementów przygotowania narodu do wojny, wspierania jej albo też kontynuacji innymi metodami” (Čolović 2007: 90). Przyczynkiem dla powstania „kulturkampfu" były poglądy byłego prezydenta Serbii Slobodana Miloševicia, który na trzy dni przed upadkiem jego rządów (5 października 2000), ostrzegał przed grożącą serbskiej tożsamości narodowej katastrofą. Kierowały nim przede wszystkim polityczne aspiracje do utrzymania władzy w państwie więc z uporem zalewał naród szczegółowymi opisami wyginięcia serbskiej kultury symbolicznej. Następca Miloševicia Vojislav Koštunica, już na samym początku swojej kadencji, troskę o symbole narodowe uczynił podstawą programu politycznego nowego rządu. Jego werbalizacja idei „kulturkampfu” posunęła się nawet do stwierdzenia, że naród serbski może zniknąć, jeśli nie dokona się szybko odnowa jego przestrzeni duchowej (tamże 2007: 88).

Transformacja tożsamości serbskiej w stadium nacjonalizmu radykalnego wyodrębnia kilka obszarów dyferencjacji obecnych w dyskursie tej tożsamości. Po pierwsze, heterogenizacja objawia się rozbiciem języka serbsko-chorwackiego na dwa odrębne systemy językowe. W efekcie, w języku serbskim unika się wariantów zachodnich natomiast w chorwackim serbizmów. Drugi obszar niejednorodności stanowi religia. Chodzi tutaj nie tylko o rozróżnienie, oddzielenie od siebie katolicyzmu chorwackiego i serbskiego prawosławia, ale bardziej o trzy wyznania religijne zajmujące terytorium Serbii. Oprócz dominującej religii prawosławnej wyróżniamy islam praktykowany przez Albańczyków w Kosowie oraz katolicyzm ulokowany w Wojwodinie. Po trzecie, silny wpływ na dyskurs posjugosłowiańskiej serbskiej tożsamości narodowej ma antagonizm serbski-chorwacki. Jego podłoże tkwi w różnorodnych interpretacjach idei jugoslawizmu. Konflikt doszedł do głosu jeszcze zanim Chorwacja uzyskała niepodległość. Od 1990 roku walki zbrojne toczyły 
się głównie między częścią żyjącej w Chorwacji społeczności serbskiej a chorwacką policją i gwardią narodową. Dla secesjonistów i opinii medialnej Chorwacja stała się wtedy ofiarą agresji ze strony Serbów, a armię serbską traktowano jako armię jugosłowiańską czyli komunistyczną. Prawdziwą przyczyną obopólnej interwencji zbrojnej nie była rzekoma „agresja serbska”, lecz dążenie Serbów mieszkających na ziemiach dawnego Pogranicza Wojskowego do uzyskania autonomii terytorialnej, a później do secesji. Zdecydowana i uporczywa odmowa władz chorwackich doprowadziła do wybuchu wojny domowej o charakterze etnicznoreligijnym. W 1995 roku armia chorwacka zaatakowała ze wszystkich stron republikę Serbskiej Krajiny, serbska ludność zaczęła uciekać z miast, w rejonach Krajiny rozpoczął się exodus. ${ }^{1}$ Antagonizm doprowadził do czystki etnicznej. W 1998 roku ziemie pogranicza opuściło 47 tys. Serbów, którzy czuli się zmuszeni to uczynić, bo grożono im śmiercią, niszczono ich plony, napastowano ich. Czwarty obszar dotyczy antagonizmu serbsko-albańskiego. Wyróżniamy w nim dwie płaszczyzny sporu: pierwsza odnosi się do wspomnianych już różnic wyznaniowych, druga dotyka problemu Kosowa zarówno w sensie terytorialnym jak i symbolicznym. Ten ostatni aspekt ma również duże znaczenie podczas kandydowania Serbii do Unii Europejskiej. Państwa członkowskie starają się bowiem nakłonić oba kraje do nawiązania dialogu. Piąty i ostatni wymiar dyferencjacji odnosi się do serbskiego etnomitu politycznego. Różnice budowane są tutaj na zasadzie dipoli, a poszczególne kategorie mitu służą wskazaniu cech i zdarzeń właściwych jedynie serbskiemu narodowi. Jedną z głównych par opozycyjnych tworzą Serbia i „Zgniły Zachód” lub „Baba Europa”.

W latach 2006-2008 na kształtowanie się serbskiej tożsamości narodowej miał wpływ tzw. nacjonalizm umiarkowany. Jest on próbą wypracowania zbiorowej samowiedzy w oparciu o cechy właściwe serbskiej przestrzeni duchowej. Z założenia nacjonalizm ten ma być „dobry” i wolny od etnicznego rasizmu. Niestety zrealizowanie takiego założenia nie jest możliwe w przestrzeni społecznej pełnej uprzedzeń, stereotypów oraz nieprzepracowanych doświadczeń wojennych. Przykładem jest sytuacja ogłoszenia niepodległości Kosowa dnia 17 lutego 2008 roku,

1 Dokonana w ten sposób czystka etniczna była konsekwencją polityki prowadzonej przez prezydenta Chorwacji, Franjo Tudjmana, posiadającego poparcie administracji USA oraz znakomicie uzbrojoną i zorganizowaną armię. 
która do dyskursu serbskiego przywróciła fragmenty retoryki nacjonalizmu radykalnego.

Od 2008 roku na dyskurs postjugosłowiańskiej serbskiej tożsamości narodowej nakładają się wciąż takie kwestie jak: brak zgody na niepodległość Kosowa, niezrealizowana rewizja historyczna, nierozliczona kwestia wojny domowej, zawieszenie pomiędzy przeszłością a teraźniejszością, borykanie się z problemem definicji tożsamości narodowej na poziomie społecznym i jednostkowym.

Slobodan Naumovic zauważa, że istnieją w dyskursie o narodzie serbskim narracje przestawiające cztery różne oblicza współczesnej Serbii:

„(1) Istnieje Serbia wierna swojej historii, tradycji, zwrócona w stronę kościoła, w stronę swoich bohaterów, przodków i potomków. To jest prawdziwa Serbia, nasza Serbia, jedyna możliwa Serbia, dumna Serbia.

(2) Jest jeszcze inna Serbia, która jest hańbą dla nazwy, którą nosi. Reprezentowana przez załogę lokajów, tchórzy, renegatów i zło. Reprezentowana przez nie Serbów, którzy myślą, że będą sprzedawać naszych bohaterów i naszą wolność za garść dolarów, a z nas uczynią swoich niewolników. Ale jeśli stawimy im opór, zjednoczeni w wierze w prawdziwą ojczyznę, złość spłynie jak łza po twarzy, tylko jedna, a Serbia znów będzie wielka i wolna.

(3) Istnieje Serbia kłamstwa, oszustwa, mitów i nienawiści. To jest Serbia patriarchalna, kolektywistyczna, anty-zachodnia i antynowoczesna. Jest manipulowana przez przywódców, którzy cynicznie wykorzystują swój prymitywizm, ignorancję i głupotę.

(4) Ale jest jeszcze Serbia miejska, nowoczesna, pacyfistyczna, kosmopolityczna, liberalna, demokratyczna i europejska. Oferuje ona jedyną możliwą przyszłość dla wszystkich, nie ma żadnej alternatywy. Będziemy ciężko pracować z naszymi zagranicznymi sąsiadami, aby zreformować obecną Serbię, tak, aby zasłużyła na europejską przyszłość, która ją czeka. Ale ta przyszłość jest możliwa tylko wtedy, gdy możemy usunąć brzydką twarz Serbii, widmo Serbii, koszmar Serbii" (Naumovic 2007: 8).

Narracje te ukazują cztery różne wizje Serbii, składające się na konteksty polityczne wytworzone we wczesnych latach 90-tych i reaktywowane współcześnie. Pierwszy opis ukazuje Serbię jako typ idealny, niepodzieloną, nieuwikłaną w konflikt, nieskażoną wojną. Drugi obraz to 
Serbia z czasów wojny domowej postawiona w opozycji do Stanów Zjednoczonych, waleczna, anty-zachodnia. Trzecia Serbia przywodzi na myśl nacjonalizm radykalny, falsyfikowanie zastanej rzeczywistości, kontrolowanie zbiorowej pamięci i przyzwolenie na kłamstwo polityczne. Ostatni czwarty opis pokrywa się z programem prozachodniego rządu koalicyjnego w Belgradzie, którego celem jest nie tylko przystąpienie Serbii do struktur Unii Europejskiej, ale także poprawa jej wizerunku na arenie międzynarodowej.

\section{Serbia w Unii Europejskiej?}

Postjugosłowiańska serbska tożsamość narodowa jest zgodnie z tezą niniejszego artykułu zorientowana na heterogeniczność (niejednorodność, odróżnienie). Jest to tożsamość w trakcie procesu transformacji, której samowiedza sytuuje się pomiędzy kształtowaniem serbskiej polityki i świadomości poprzez bohaterskie pieśni ludowe z czasów niewoli tureckiej, a potrzebą zakorzenia w zastanej rzeczywistości społecznej, narodowej i transnarodowej. Ten drugi aspekt koresponduje bezpośrednio z ideą członkowstwa Serbii w Unii Europejskiej.

Na początku trzeba jednak nawiązać do bałkańskiego quasi kolonializmu, który jako dyskurs utrwala i ustanawia zależności między konstruktem Europy i konstruktem Bałkanów. „To perspektywa Europy, która patrzy na Bałkany przez weneckie lustro samozadowolenia, dominacji i dyskredytacji" (Zieliński 2008: 41). Zdaniem Marii Todorovej: „tranzytowy charakter Bałkanów, jego międzypołożenie sprawiło, że Bałkany ukonstytuowały się nie tylko, jako <<inny >>, ile <<niezupełnie swój>>" (Todorova, 1997: 18). Božidar Jezernik, słoweński etnolog i antropolog kulturowy uważa, że gdy słowa Bałkany zaczyna się używać w szerszym znaczeniu niż nazwa masywu górskiego w Bułgarii, natychmiast zyskuje ono negatywne, nacechowane ideologicznie konotacje: brudu, pasywności, niewiarygodności, nieposzanowania praw kobiet, spisków, braku skrupułów, oportunizmu, gnuśności, przesq̨ów, ospałości, pozbawionej zasad, nadgorliwej biurokracji itp. Z tego powodu nawet w rodzimych, bałkańskich językach, słowo Balkan stało się synonimem braku cywilizacji i zacofania. (zob. Jezernik 2004: 15).

Bogusław Zieliński prezentuje pięć klisz poznawczych (wyprowadzonych z narracji Europy) umiejscowionych w dyskursie dotyczącym wojny postjugosłowiańskiej: 
Bałkany to trudna, porzucona granica. Są oddzielone granicą od Europy, ale także mury dzielą poszczególne bałkańskie kraje miedzy sobą. Bałkany tworzą granicę niechęci lub nienawiści z najbliższymi sąsiadami.

Bałkany to „boczna furtka” Europy, gdzie lepiej nie zachodzić. Kamień (kula) u nogi Europy, a także obszar spraw trudnych i niebezpiecznych. Ten kompleks semantyczny wyrażają określenia: „węzeł bałkański”, „kocioł bałkański”, „Bałkany - miękkie podbrzusze Europy”.

Bałkany to obszar „bałkanizacji”, czyli obszar permanentnych konfliktów, źródło nieporządku, walk wszystkich ze wszystkimi, obszar chaosu, parcjalizacji separatyzmów („państw kieszonkowych”).

Bałkany to obszar zacofania kulturowego i cywilizacyjnego, prymitywizmu, brudu, braku uprzejmości, samowoli, intymności, zażyłości i komizmu.

Bałkany to obszar odwróconego porządku, orientalizmu, cielesności i zmysłowości, zemsty, mściwości, okrucieństwa. Duch Bałkanów to duch permanentnego konfliktu, gdyż zamieszkiwany jest przez prymitywne rasy, które kontynuują odwieczną walkę każdym. Narody bałkańskie są lunatykami w czasie pokoju, budzącymi się do realnego życia w czasie wojny (Zieliński B., 2008: 41-43).

Serbski mit polityczny, z kolei, kontrast i przeciwieństwo Wielkiej Matki Serbii przypisuje złemu bóstwu znanemu jako „Zgniły Zachód” lub „Baba Europa”. Vladimir Velmar-Janković, zauważył, że: „Serb to nieEuropejczyk. Ze wszystkich krain świata Bałkany w najmniejszym stopniu są Europą" (Čolović 2001: 51). W mitologicznej fabule narodowej Serbowie przedstawieni zostali jako strażnicy pierwotnej europejskości. W przeciwieństwie do innych narodów nie są jedynie „turystami historii”, zachowali bowiem charakter narodowy, tradycję i ciągłość świadomości narodowej stanowiącej element trwałości silnej tożsamości narodowej. W pierwszej części mitu o narodzie serbskim czytamy: „(...) naród ów istnieje na uboczu czasu historycznego, bezpowrotnego trwonienia historii" (tamże 2001: 18). Ideę, iż Europa narodziła się w Serbii głosi między innymi czarnogórski poeta Matija Bećković twierdząc, że: „Europa nie ma głębszego korzenia niż ten, który poprzez Grecję i Bizancjum kiełkuje na naszej ziemi" (Čolović 2007: 53). Rosyjski pisarz Władimir Wołkow dodaje, że: „Serbowie dają Europejczykom przykład, jak trzeba bronić substancji narodowej, wartości duchowych i tradycji, humanizmu i etyki. Jeśli Europejczycy pójdą za przykładem Serbów, uratują się i od- 
rodzą" (tamże 2007: 53). Ten topos wyższości serbskiej krainy nad „Zgniłym Zachodem” tłumaczyć może wcześniejszy topos o prymitywizmie narodów bałkańskich wobec rozwiniętego świata Zachodu. Topos serbski staje się ripostą, polemiką z wyobrażeniami na temat kultury bałkańskiej projektowanymi przez Zachód.

We wspomnianym już przemówieniu, wygłoszonym na obchodach sześćsetlecia bitwy na Kosowym Polu, Slobodan Milośević objaśnił: „Przed sześciu wiekami Serbia tutaj w Kosowie, broniła siebie. Ale broniła też Europy. Była wtedy na jej szańcach, gdzie strzegła europejskiej kultury religii, całej społeczności Europy. Dlatego dzisiaj nie tylko niesprawiedliwa, ale sprzeczna z historią i wręcz absurdalna jest rozmowa o przynależności Serbii do Europy" (Daković 2004: 201-202).

Do źródeł antyeuropejskich tekstów serbskiej kultury należą także dzieła prawosławnych teologów. Najbardziej znaczącej krytyki kultury europejskiej dokonali dwaj prawosławni teologowie: Nikołaj Velimirović (1889-1956) i Justin Popović (1894-1979). Ich krytyka skupia się na humanizmie cywilizacji europejskiej i duchu materializmu, który opanował ich zdaniem świat Zachodu. Wspominali oni również o bezbożności europejczyków i „zgniłości” ich duszy. Dzisiejsi nosiciele serbskiego mitu nacjonalnego, wyznają poglądy zaproponowane przez Velimirovicia i Popovicia, czego fundamentalnym przykładem jest wypowiedź młodego historyka Dragana Subotića: „Prawosławny Słowiański Wszechczłowiek, to historyczne przeciwieństwo konsumpcyjnej, zubożałej duchowo i pozbawionej przewodnictwa „rzymskiej” Europy” (Čolović 2007: 58 - 59).

Obecne nastawienie proeuropejskie, promowane w Serbii przez prozachodni rząd koalicyjny, odchodzi od mitów i historycznych sporów stawiając na pierwszym miejscu ekonomiczne i społeczne korzyści płynące dla Serbii w momencie jej wstąpienia do UE. Niestety, mimo iż politycy starają się ominąć kwestie quasi kolonialnego bałkanizmu oraz serbskich resentymentów, stawiane przed Republiką Serbii zadania odsyłają rząd i mieszkańców do rozliczenia z przeszłością historyczną. Warunkiem przyjęcia Serbii do Unii jest współpraca Belgradu z Międzynarodowym Trybunałem Karnym dla Byłej Jugosławii w Hadze. Serbii wciąż nie udało się aresztować m. in. przywódcy bośniackich Serbów Ratko Mladicia, poszukiwanego za zbrodnie wojenne na terenach byłej Jugosławii w czasie minionej wojny bałkańskiej. Kolejny problem stanowi wymóg ze strony Unii dotyczący nawiązania przez Serbię dialogu 
z Kosowem pod auspicjami UE. Serbia, co prawda zgodziła się na ten warunek i przystała na podjęcie rozmów z Prisztiną, ale jedynie ze względu na europejskie aspiracje Belgradu. Rząd Serbii, mimo wejścia $\mathrm{w}$ dialog z Kosowem, nie zmienił zdania i nadal nie uznaje ogłoszonej w lutym 2008 roku niepodległości swojej dawnej prowincji. Unia Europejska, ze swojej strony, od końca lat 90-tych pomaga Serbii rozwiązać problem deficytu dostaw energii elektrycznej, który zaistniał na szeroką skalę po zbombardowaniu Republiki Serbii przez NATO.

Oprócz kwestii formalnych idea członkostwa Serbii w Unii Europejskiej zakłada również spotkanie dyskursu postjugosłowiańskiej serbskiej tożsamości narodowej z konstruktem tożsamości europejskiej. Historycznie te dwa konstrukty zetknęły się w IX wieku, w momencie narodzin staroserbskiej literatury. ${ }^{2}$ Natomiast osłabienie Bizancjum, związane z IV wyprawą krzyżową (lata 1202-1204), spowodowało ożywienie kulturalne w zjednoczonej Serbii i sąsiedniej Bułgarii. Suwerenna i niezależna Serbia opowiedziała się w ostateczności po stronie Bizancjum, co pozwoliło jej na kontakt z najwyższą i najbogatszą podówczas kulturą europejską (Naumow 1983: 226). W chwili powstania literatura ta stała się częścią wspólnoty kulturowej Słowian obrządku wschodniego. Była to przede wszystkim literatura chrześcijańska i słowiańska i w takiej formie oddziaływała na literaturę bułgarską, słowiańsko-rumuńską, rosyjską i bizantyjską. Dzięki wschodniej orientacji, kultura serbska zyskała „dużą uniwersalność w świecie bizantyńsko-słowiańskim” (tamże 1983: 227). Współczesne serbskie pieśni folklorystyczne, baśnie oraz polityczne etnomity zawierają figury retoryczne charakterystyczne właśnie dla dawnej literatury cerkiewnosłowiańskiej. Średniowieczne akcenty patriotyczne przeradzają się przecież w elementy konstytutywne serbskiego nacjonalizmu, a ofiarność i religijność narodu jest według

2 Stworzenie kultury słowiańskiej tuż obok rozwijających się wówczas kultur greckiej (bizantyńskiej) i łacińskiej stanowiło dla ówczesnych Słowian swego rodzaju misję, „posłannictwo dziejowe”. Wkrótce po stłumieniu zaczątków owego "posłannictwa” na Morawach i w Panonii (za sprawą niemieckich łacinników), centrum rozwoju kultury Słowian zostało przeniesione do Bułgarii, do której terytorium należały wówczas również: część dzisiejszej Serbii i Macedonia. W roku 971 wschodnia Bułgaria dostała się do niewoli Bizantyjczyków, natomiast ciągłość rozwoju kultury słowiańskiej uratowały najpierw Macedonia (lata 971-1014) a następnie Ruś Kijowska, która korzystając z osiągnięć Słowian bałkańskich w 1240 roku przeżyła rozkwit swojej kultury. 
mitów narodowych czynnikiem wartościującym pozycję Serbii w świecie żywych i umarłych.

Kontakt Republiki Serbii z kulturą europejską rozpoczął się poprzez dyfuzję. Biorąc pod uwagę wiedzę historyczną, Republika Serbii była dość silnie związana z kulturą i tradycją europejską. Odwrócenie się od Europy spowodował bałkański quasi kolonializm oraz podkreślanie przez Zachód nieeuropejskiego charakteru Serbii podczas ostatniej wojny domowej na Bałkanach. Ożywienie poczucia przynależności Serbii do Europy jest zadaniem do zrealizowania przez obydwa omawiane regiony.

\section{Zakończenie}

Rozpoczęty proces realizacji warunków członkostwa Serbii w Unii Europejskiej nasuwa dwa pytania: (1) czy postjugosłowiańska serbska tożsamość narodowa zrezygnuje z prezentowanych - wciąż silnych postaw nacjonalistycznych na rzecz transnarodowej wymiany kulturowej, w imię otwartości i tolerancji wobec tego, co „obce”? (2) czy też może kolejna próba zewnętrznej ingerencji w kształtowanie się elementów dyskursu serbskiej tożsamości przywróci dawne resentymenty i w konsekwencji doprowadzi do ponownej próby zbudowania tożsamości „nieeuropejskiej”? Optymistyczne spojrzenie na sprawę mogłoby sugerować duże prawdopodobieństwo odpowiedzi twierdzącej na pytanie pierwsze. Nie oznacza to oczywiście, że scenariusz taki ma małe szanse na realizację. Świadczy to raczej o jeszcze długiej drodze, w trakcie której kształtowana dyskursywnie serbska tożsamość narodowa musi przepracować samą siebie jako wiedzę. Z dotychczasowych działań unijnych wynika dość jasno, że Republika Serbii aby wejść do struktur Unii i w nich pozostać, musi podporządkować się standardom oraz spełnić wymagane warunki - narzucające okcydentalną europejską perspektywę postrzegania serbskiego nacjonalizmu.

Nakreślone powyżej scenariusze realizacji procesu dostosowania się Republiki Serbii do stawianych jej przez UE wymagań, można również skonfrontować z dynamiką stosunków pomiędzy UE a społeczeństwami muzułmańskimi w Europie. Muzułmanie mieszkający w krajach UE pochodzą z Turcji, Afryki Północnej, Bliskiego Wschodu, krajów byłej Jugosławii, Bangladeszu i Pakistanu. Znaczna ich część posiada obywatelstwo Unii Europejskiej.

Dla społeczeństw muzułmańskich egzystencja w krajach Unii oznacza realizację jednej z trzech możliwych dróg integracji. Pierwsza z nich 
zakłada integrację całkowitą, którą charakteryzuje rezygnacja z odmienności wyznaniowo-kulturowej na rzecz przejęcia tożsamości europejskiej. Nie oznacza ona odrzucenia narodowej tożsamości religijnokulturowej, przekłada się raczej na kultywowanie jej w sferze życia prywatnego, natomiast w kontekście społecznym, publicznym wymaga dostosowania się do reguł braku możliwości eksponowania swojej kultury i wyznania poprzez strój, język, gromadzenie się w meczetach.

Druga droga dotyczy zachowania i eksponowania odmienności swojej tożsamości muzułmańskiej, co zazwyczaj prowadzi do wyobcowania z lokalnego społeczeństwa. Sytuacja ta, podobnie jak w przypadku nacjonalizmu serbskiego, napotyka na konflikt pomiędzy okcydentalną perspektywą europejską a narodową optyką muzułmańską, na którą ta pierwsza - okcydentalna - patrzy nieprzychylnie i ze strachem.

Trzecia droga jest tzw. wyjściem pośrednim, próbującym połączyć dwie wcześniejsze opcje. Jest to tzw. integracja przy jednoczesnym pozostaniu muzułmaninem zgodnie z zasadami swojej religii. Twórcą takiego rozwiązania jest Tariq Ramadan europejski muzułmanin, islamolog, znawca zagadnień związanych z obecnością islamu w Europie. Ramadan twierdzi, że tożsamość muzułmańska w strukturach europejskich bywa często tylko pozornie ocalona. Dzieje się tak poprzez redukcję islamu do obszaru tradycyjno-kulturowego, odbierając mu przez to aspekt uniwersalizmu, który charakteryzuje religię muzułmańską (Ramadan 1999: 303). Owy uniwersalizm islamu przekłada się na założenie, że wartości czerpane ze źródeł tej religii i kultury, nie są w żaden sposób odmienne od wartości europejskich takich jak: wolność, równość, demokracja zagwarantowanych w konstytucjach. Zdaniem Ramadana europejski muzułmanin jako obywatel państwa europejskiego, nie musi rezygnować ze swojej religijnej, duchowej i kulturowej tożsamości. Ramadan propaguje tzw. „islam europejski” polegający na redefinicji swojej tożsamości z pozycji bycia „muzułmaninem w Europie” na rzecz „bycia muzułmaninem europejskim". Proponuje więc odejście od skupiania się na swojej odrębności religijno-kulturowej i realizację idei bycia aktywnym członkiem społeczeństwa europejskiego jako „europejski muzułmanin”.

Postawa Unii wobec społeczności muzułmańskiej w Europie nie jest jednak, tak jak Ramadan, skłonna głosić tzw. „islam europejski”, jako drogę wzajemnej integracji. Prezentowane formy redefinicji bądź ochrony przez „muzułmanów w Europie” ich religijno-kulturowej tożsamości, 
mogą być podstawą dla umocnienia nacjonalistycznie zorientowanych środowisk serbskich w słuszności swego stanowiska. Należy jednak pamiętać, że mimo licznych podobieństw obu procesów integracji, Serbowie nie są dla zjednoczonej Europy problemem w aspekcie religijnokulturowym, który stanowi główną kość niezgody w stosunkach między Unią a społeczeństwami muzułmańskimi w Europie.

\section{Bibliografia:}

Bokszański Z. (2001) Stereotypy i kultura, PWN, Warszawa.

Bokszański Z. (2008) Tożsamości zbiorowe, PWN, Warszawa.

Cillia R., Reisigl M., Wodak R. (1999) The discursive construction of national Identities, Edinburgh University Press, Edinburgh.

Čolović I. (2007) Bałkany - terror kultury, Wyd. Czarne, Wołowiec.

Čolović I. (2001) Polityka symboli, Universitas, Kraków.

Daković N. (2004) The Balkans and the West, Contructing the European Other, 1945- 2003, Agshate Publishing, Cornwall, s. 199- 212.

Dąbrowska-Partyka M. (1995) Jad złej pamięci, „Znak”, nr 5 .

Jezernik B. (2004)„Dzika Europa. Bałkany w oczach zachodnich podróżników, Universitas, Kraków.

Konarski W. (2006) Nacjonalizm i pojęcia powiq̨zane. Interpretacje autorskie oraz wybrana egzemplifikacja" [w:] Bałkany. Etnokulturowe podłoże konfliktów, Wyższa Szkoła Humanistyczna imienia Aleksandra Gieysztora, Pułtusk .

Łatuszyński G. (1997) Bałkańskie przekleństwo, Agawa, Warszawa.

Naumow A. E. (1983) Dar Słowa, Wydawnictwo Łódzkie, Łódź.

Naumovic S. (2007) On "Us" as "Them". Understanding the historical bases and political uses of popular narratives on Serbian disunity [w:] How to think about Balcans: culture, region, identity, CAS Working Paper Service, Issue 1, Sofia University.

Ramadan T. (1999) Entre musulman européen, Tawhid Ed, Lyon.

Rapacka J. (2002) Śródziemnomorze, Europa Środkowa, Bałkany : studia z literatur południowosłowiańskich, Universitas, Kraków.

Todorova M. (1997) Imagining the Balkans, Oxford University Press, New York.

Waldenberg M. (2003), Rozbicie Jugosławii. Od separacji Słowenii do wojny kosowskiej, Scholar, Warszawa.

Zieliński B. (2008), Obraz Słowiańszczyzny południowej w polskim dyskursie publicznym III Rzeczpospolitej (po 1989 roku) [w:] B. Zieliński (red.,, Tradycje Pogranicza i przestrzenie tradycji od komunizmu do postmodernizmu i postkolonializmu, wyd. Uniwersytetu im. Adama Mickiewicza, Poznań, s. 35 - 50. 